\title{
Distinctive effects of allochthonous and autochthonous organic matter on CDOM spectra in a tropical lake
}

\author{
Luciana Pena Mello Brandão ${ }^{1,2}$, Ludmila Silva Brighenti ${ }^{1}$, Peter Anton Staehr ${ }^{2}$, Eero Asmala ${ }^{3}$, Philippe Massicotte $^{4}$, \\ Denise Tonetta $^{5}$, Francisco Antônio Rodrigues Barbosa ${ }^{1}$, Diego Pujoni ${ }^{1}$, and José Fernandes Bezerra-Neto ${ }^{1}$ \\ ${ }^{1}$ Limnea, ICB, Universidade Federal de Minas Gerais, Av. Antonio Carlos, 6627, Pampulha, Belo Horizonte, \\ Minas Gerais, Brazil \\ ${ }^{2}$ Department of Bioscience, Aarhus University, Frederiksborgvej, 399, 4000 Roskilde, Denmark \\ ${ }^{3}$ University of Helsinki, Tvärminne Zoological Station, J.A. Palménin tie 260, 10900 Hanko, Finland \\ ${ }^{4}$ Departament of Biology, University of Laval, Pavillion Alexandra-Vachon 1045, av. De la Medecine, local 2078, \\ Québec, Canada \\ ${ }^{5}$ Limnos, ECZ, Universidade Federal de Santa Catarina, Campus Universitário Reitor João David Ferreira Lima, Trindade, \\ Florianópolis, Santa Catarina, Brazil
}

Correspondence: Luciana Pena Mello Brandão (lucianapmb@hotmail.com)

Received: 10 November 2017 - Discussion started: 8 February 2018

Revised: 13 April 2018 - Accepted: 19 April 2018 - Published: 16 May 2018

\begin{abstract}
Despite the increasing understanding about differences in carbon cycling between temperate and tropical freshwater systems, our knowledge on the importance of organic matter $(\mathrm{OM})$ pools on light absorption properties in tropical lakes is very scarce. We performed a factorial mesocosm experiment in a tropical lake (Minas Gerais, Brazil) to evaluate the effects of increased concentrations of allochthonous and autochthonous OM, and differences in light availability on the light absorption characteristics of chromophoric dissolved organic matter (CDOM). Autochthonous OM deriving from phytoplankton $(\sim \mathrm{Chl} a)$ was stimulated by addition of nutrients, while $\mathrm{OM}$ from degradation of terrestrial leaves increased allochthonous OM, and neutral shading was used to manipulate light availability. Effects of the additions and shading on DOC, Chl $a$, nutrients, total suspended solid concentrations (TSM) and spectral CDOM absorption were monitored every 3 days. CDOM quality was characterized by spectral indices $\left(S_{250-450}, S_{275-295}\right.$, $S_{350-450}, S_{\mathrm{R}}$ and $\left.\mathrm{SUVA}_{254}\right)$. Effects of carbon sources and shading on the spectral CDOM absorption was investigated through principal component (PCA) and redundancy (RDA) analyses. The two different OM sources affected CDOM quality very differently and shading had minor effects on OM levels, but significant effects on OM quality, especially in combination with nutrient additions. Spec-
\end{abstract}

tral indices $\left(S_{250-450}\right.$ and $\left.S_{\mathrm{R}}\right)$ were mostly affected by allochthonous OM addition. The PCA showed that enrichment by allochthonous carbon had a strong effect on the CDOM spectra in the range between 300 and $400 \mathrm{~nm}$, while the increase in autochthonous carbon increased absorption at wavelengths below $350 \mathrm{~nm}$. Our study shows that small inputs of allochthonous OM can have large effects on the spectral light absorption compared to large production of autochthonous OM, with important implications for carbon cycling in tropical lakes.

\section{Introduction}

Organic matter $(\mathrm{OM})$ consists of particulate organic matter (POM; organic compounds represented by aquatic communities and detritus) and dissolved organic matter (DOM - in most DOM studies it is the compounds smaller than 0.2 or $0.7 \mu \mathrm{m})$, which is by far the largest pool of organic carbon in aquatic systems (Hedges, 1992). A better understanding of carbon cycling in aquatic environments and its regional and global importance therefore requires knowledge of the biogeochemical processes involved in the transformation, production and mineralization of DOM (Bertilsson and Tranvik, 2000; Johannessen et al., 2007; Tranvik et al., 2009). 
The main sources of DOM in aquatic ecosystems can be divided into two main categories: the allochthonous pool, which comes from terrestrial vegetation and soil sources (Kieber et al., 2006; Miller et al., 2009), and the autochthonous pool which is produced by aquatic primary producers (Kritzberg et al., 2004; Guillemette and Del Giorgio, 2012). These two DOM pools have fundamental differences in their optical and chemical characteristics which in turn influence the mechanisms by which DOM is degraded (Wetzel et al., 1995; Bertilsson and Tranvik, 2000). The allochthonous DOM is considered to be more susceptible to photodegradation because it contains relatively large molecules with high numbers of aromatic compounds which strongly absorb UV light (Amon and Benner, 1994; McKnight et al., 1994; Benner, 2002; Helms et al., 2008). The autochthonous DOM originating from phytoplankton mainly consists of simple molecules (carbohydrates, proteins, amino acids) of low molecular weight and is typically more labile for microbial community (Farjalla et al., 2009; Fonte et al., 2013).

The rate of photodegradation depends on a combination of available sunlight and the chemical characteristics of DOM (Benner, 2002), whereas the microbial degradation rate depends on the inherent DOM bioavailability and the utilization efficiency of the bacterial community (Catalán et al., 2013; Asmala et al., 2014), and both are important processes that transform and remove DOM in aquatic ecosystems (Roland et al., 2010; Mopper et al., 2015). Photodegradation is also known to transform DOM to ammonia and other highly bioavailable compounds (Aarnos et al., 2012), which can be an important nutrient supply for both phytoplankton (Hessen and Tranvik, 1998) and heterotrophic bacterial communities (Kieber et al., 1989; Miller et al., 2002; Lønborg et al., 2010). The microbial uptake of DOM by heterotrophic organisms converts it to POM, which in turn can be assimilated by protozooplankton through the microbial loop (Azam et al., 1983). Additionally, biodegradation of DOM can be stimulated by inorganic nutrients, mainly nitrogen and phosphorus, which increase the bacterial growth efficiency (Zweifel et al., 1995; Asmala et al., 2013) by reducing the energetic cost of substrate acquisition (Hopkinson et al., 1998). In tropical lakes, aquatic processes including mineralization of organic compounds occur more rapidly than in temperate lakes due to high temperatures and water light availability throughout the year (Marotta et al., 2010). However, there are only few studies on the photochemical (Teixeira et al., 2013; Bittar et al., 2015) and bacterial (Farjalla et al., 2002; 2009; Roland et al., 2010) degradation of DOM in tropical environments compared to temperate freshwater systems and estuaries (Bertilsson and Tranvik, 2000; Anesio and Granéli, 2003; Boreen et al., 2008; Asmala et al., 2014; Attermeyer et al., 2015).

The drivers of DOM dynamics in tropical environments are different from those in temperate environments, because in the tropics the seasonality of rainfall is the main driver for allochthonous contribution to the aquatic system (Suhett et al., 2006) and in temperate systems it is related to changes in temperature (such as by the flow of the melting water in the surroundings or by the destratification of lakes; Lindell et al., 2000). Brazil has a variety of complex freshwater systems that behave in different ways regarding the temporal dynamics of DOM. For example, in most tropical rivers and lakes, the seasonal allochthonous contribution occurs via runoff in the rainy season (between September and April), raising humic carbon concentrations and water color (Farjalla et al., 2002). In some regions, such as the complexes of Brazilian rivers and Amazonian lakes, the contribution of allochthonous material is related to the hydrological pulse, which raises the level of the water invading the surrounding forests (Amado et al., 2006).

The lake system of the Middle Rio Doce is composed of about 300 natural lakes and is among the three most important in Brazil, behind the Amazonian and Pantanal basins (Maillard et al., 2012). Many of these lakes are used by the local population both for water supply for human consumption and for water use in economic activities such as agriculture, livestock and large mining companies present in the region. Fishing is also an important activity in this region. Recent studies in this region have shown that the marked seasonality in the inputs of allochthonous material (nutrients and organic matter) during periods of rain (thermal stratification period, summer) plays a key role in the pattern observed for the optical characteristics of lakes, for example the transparency to photosynthetically active radiation (PAR) and ultraviolet (UV) (Gagliardi, 2015; Brandão et al., 2016). Contrary to expectations, greater transparency of these lakes is observed during the rainy season, since the allochthonous material remains trapped in the hypolimnium by temperature difference, until the water mixture (dry season, winter) redistributes it throughout the water column (Reynolds, 2009; Brandão et al., 2016). In this context, higher net phytoplankton production rates occur in the mixing periods, with lower solar radiation incidence and lower transparency (Brighenti et al., 2015). Bezerra-Neto et al. (2006) showed a strong negative influence on the concentration of CDOM (chromophoric dissolved organic matter) and transparency to the PAR radiation in a set of lakes of this lacustrine system, which emphasizes the importance of the chromophoric carbon from allochthonous origin for the physical and chemical conditions of the lakes, and consequently seasonal dynamics of phytoplankton and aquatic metabolism. In this way, the physical, chemical and ecological balance of these lakes is strongly affected by inputs of nutrients and organic matter from the catchment during the rainy season. However, the frequency and intensity of precipitation events in this region has changed over the last decade (Roland et al., 2012). In addition, the Atlantic Forest is a threatened and extremely devastated biome (Myers et al., 2000) and most of the lakes have already had the surrounding forest replaced by eucalyptus and pasture plantations. Land use transformation and the 
disruption of biogeochemical cycles may change the amount and quality of the inputs of dissolved nutrients (such as phosphate and nitrogen compounds) and organic matter into the lake (Vitousek et al., 1997; Pinheiro et al., 2015), changing the balance between allochthonous and autochthonous DOM sources in the systems and consequently DOM degradation pathways. In addition, tropical lakes are considered hot spots for biodiversity and greenhouse gas cycles, and furthermore they are believed to be highly sensitive to climate changes causing profound changes of lake physical (i.e., volume, area, stratification) and chemical (i.e., dissolved oxygen, nutrients, organic matter) conditions with ultimate effects on regional carbon cycling.

Some recent studies have demonstrated that DOM transformations (such as the effect of photodegradation and biodegradation on the absorption properties of CDOM) was not constant over the spectral range, thus influencing the shape of the absorption curve (Helms et al., 2013; Reader et al., 2015). As modifications in the spectral shape reflect underlying changes in the carbon compounds at the molecular level, studies on biological and chemical effects on CDOM spectra allow a better understanding of the DOM transformations and how this links to overall carbon cycling in aquatic ecosystems (Stubbins et al., 2014).

To investigate how the optical properties of the lakes change due to more common anthropogenic impacts (such as eutrophication, land use change) and recent regional changes in rainfall, we performed a mesocosm experiment in a local tropical lake, manipulating nutrients, OM and light conditions. We expected that addition of nutrients would stimulate algal growth and increase the production of autochthonous DOM (Schindler, 1977; Lean and Pick, 1981) until nutrients became exhausted. For comparison, addition of extracted OM from leaves of the native forest mimicked effects of increasing allochthonous DOM concentrations. We hypothesized that $\mathrm{OM}$ from different sources would change the CDOM absorption spectra and associated indices differently over time. We also investigated the effect of the two interacting OM sources on the optical characteristics of DOM. Finally, we applied a shading filter to investigate expectations of a high importance of light availability on both autochthonous OM production and variable levels of photodegradation for different pools of OM.

\section{Methods}

\subsection{Study area}

This study was conducted in Lake Carioca $\left(19^{\circ} 45^{\prime} 26.0^{\prime \prime} \mathrm{S}\right.$, $42^{\circ} 37^{\prime} 06.2^{\prime \prime} \mathrm{W}$ ), one of the approximately 300 natural lakes of the Middle Rio Doce lacustrine system, the third-most important in Brazil. It is located in the southern part of the State Park of Rio Doce (PERD, Minas Gerais, Brazil), which is the largest remnant of the Atlantic Forest in Minas Gerais
(36000 ha forest) with lakes occupying $9.8 \%$ (3530 ha) of its total area. Carioca Lake is surrounded by secondary Atlantic Forest and is a warm-monomictic lake with a mixing period during the dry winter (May to August) and thermal stratification during the rest of the year (September to April). It is a mesotrophic lake (total phosphorus: 5.6-21.4 $\mu \mathrm{g} \mathrm{L}^{-1}$, epilimnion annual average $13.9 \mu \mathrm{g} \mathrm{L}{ }^{-1}$; chlorophyll $a$ : $1.3-$ $16.6 \mu \mathrm{g} \mathrm{L}^{-1}$, epilimnion annual average $7.7 \mu \mathrm{g} \mathrm{L}^{-1}$ ) (Petrucio et al., 2006; Brighenti, 2014), with $1718.6 \mathrm{~m}$ of perimeter, $14.1 \mathrm{ha}, 671 \times 10^{3} \mathrm{~m}^{3}$, and maximum depth of $11.8 \mathrm{~m}$ and average depth of $4.8 \mathrm{~m}$ (Bezerra-Neto et al., 2010). Carioca is one of the lakes that have been monitored for water quality and aquatic biota since 2000 through the BrasilLTER Programme (PELD-CNPq Proc. 403698/2012-0). It is known that the input of DOM and nutrients in Carioca Lake occurs via runoff during the rainy season, but most of them remain below the thermocline due to temperature differences (Reynolds, 2009). During the mixing period, DOC, CDOM and nutrients become distributed in the water column, increasing their concentrations and availability in the surface layer, which in turn contributes to increased primary production and respiration rates (Brighenti et al., 2015).

\subsection{Experimental design and measurements}

To test the effect of organic matter inputs, sunlight, and nutrients on DOM degradation, we conducted an in situ experiment using a total of 16 cylindrical mesocosms (diameter $1.3 \mathrm{~m}$, height $1.5 \mathrm{~m}$ and volume $2 \mathrm{~m}^{3}$ ) with eight different combinations (two replicates for each combination). The sampling was carried out between 20 January and 1 February 2015 with daily measurements occurring between 10:00 and 12:00. Water samples ( $3 \mathrm{~L}$ at $0.5 \mathrm{~m}$ from the surface) from mesocosms were collected every 3 days. The mesocosms setup was based on a $2 \times 2 \times 2$ factorial design as follows: (1) with and without addition of organic matter extracted from leaves surrounding the lake, (2) with and without addition of nutrients $\left(\mathrm{NaNO}_{3}, \mathrm{~K}_{2} \mathrm{HPO}_{4}, \mathrm{NH}_{4} \mathrm{Cl}\right)$ and with and without $50 \%$ of shading of solar radiation (Fig. 1). Treatments with addition of organic matter are represented by the acronym OM, those with nutrients addition by NUT and those that are shaded by SH. Thereby different combinations with these acronyms give rise to the names of the different treatments as shown in Fig. 1 (for example OMNUT represents the treatments with additions of organic matter and nutrients, and OMNUTSH represents those with additions of organic matter, nutrients and shade).

The organic matter added to the mesocosms was a mixture of leaves, plant detritus and soil particles adhered to this material from the ground around the lake (four cylinders, ca. $20 \mathrm{~L}$ each). The material was placed in buckets with distilled water $(60 \mathrm{~L})$ for decomposition and stored in the laboratory under room temperature (ca. $25^{\circ} \mathrm{C}$ ). After 1 week the water was filtered with $20 \mu \mathrm{m}$ mesh and $7.5 \mathrm{~L}$ of the filtrate was added to each of the eight units 


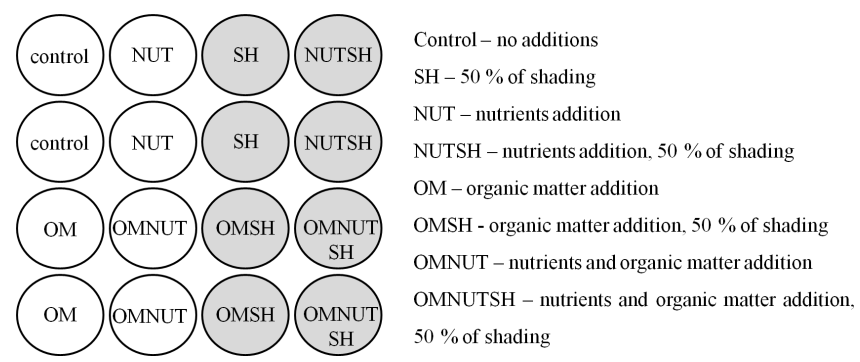

Figure 1. Schematic figure of the factorial design of mesocosms experiments.

in order to increase allochthonous organic matter availability in these mesocosms. One week of incubation of this allochthonous material is time enough for most of the existing labile DOM from the leaves and detritus to be degraded before being added to the mesocosms. The initial organic matter concentration in each of the eight carbon-amended cylinders was $8.6 \pm 0.1 \mathrm{mg} \mathrm{L}^{-1}$ (DOC, mean \pm standard deviation), $21.44 \pm 0.52 \mathrm{~m}^{-1}$ ( $a_{\mathrm{CDOM} 254}$, mean \pm standard deviation) and $0.66 \pm 0.04 \mathrm{~m}^{-1}\left(a_{\mathrm{CDOM} 440}\right.$, mean \pm standard deviation). In the eight units without organic matter addition the initial organic matter was $8.0 \pm 0.4 \mathrm{mg} \mathrm{L}^{-1}$ (DOC, mean \pm standard deviation $), 17.11 \pm 0.43 \mathrm{~m}^{-1}\left(a_{\mathrm{CDOM} 254}\right.$, mean \pm standard deviation $)$ and $0.43 \pm 0.04 \mathrm{~m}^{-1}\left(a_{\mathrm{CDOM} 440}\right.$, mean \pm standard deviation). We performed a pilot mesocosm experiment in July 2014 to study the suitable OM addition levels for the experiment. In this pilot study, we noticed that this methodology and volume of extract was enough to modify the quality of organic matter and also light attenuation levels in the organic matter added treatment (with added OM: $a_{\mathrm{CDOM} 254} 22.31 \mathrm{~m}^{-1}, \mathrm{Kd}_{\mathrm{PAR}} 1.68 \mathrm{~m}^{-1}$; without $\mathrm{OM}$ addition: $a_{\text {CDOM } 254} 16.67 \mathrm{~m}^{-1}, \mathrm{Kd}_{\mathrm{PAR}} 0.99 \mathrm{~m}^{-1}$ ).

Mesocosms were submerged on the surface of the lake and filled with lake water. Mesocosms with reduced light availability $(\mathrm{SH})$ were shaded with spectrally neutral shading screens (50\%) and only opened for quick samplings and measurements. Every day, the mesocosms were gently stirred and measured for water temperature using a Hydrolab DS5 probe (Hach Inc.). During the experiment, the water temperature of the mesocosms ranged between 28.4 and $31.3^{\circ} \mathrm{C}$ (average $30.8^{\circ} \mathrm{C}$ ).

Water samples were filtered immediately after sampling for Chl $a$ and nutrients $(0.47 \mu \mathrm{m}$ filter) and TSM (AP040 filter). The filters were kept frozen until analysis. Water samples were also filtered for analysis of DOC and CDOM $(0.22 \mu \mathrm{m}$ Millipore filter) and stored in amber glass bottles (pre-washed with distilled water and hydrochloric acid $10 \%)$ at $4{ }^{\circ} \mathrm{C}$ in the dark. The $\mathrm{Chl} a$ concentration corrected by pheophytin $\left(\mu \mathrm{g} \mathrm{L}^{-1}\right)$ was obtained by acetone extraction $(90 \%)$ measured in a spectrophotometer (UV-VIS Shimadzu) at 665 and $750 \mathrm{~nm}$ and calculated using the protocol provided in APHA (1998). The TSM $\left(\mathrm{mg} \mathrm{L}^{-1}\right)$ were determined by the gravimetric method, considering the dif- ference between the dry weights of AP40 Millipore filters $\left(105^{\circ} \mathrm{C}\right.$ for $\left.2 \mathrm{~h}\right)$ before and after the filtration of water samples (APHA, 1998). The DOC concentration $\left(\mathrm{mg} \mathrm{L}^{-1}\right)$ was obtained by catalytic oxidation method of high temperature using TOC analyzer (Shimadzu TOC - 5000A). Filtered water samples were taken for dissolved nutrients (ammonia, nitrate, nitrite and phosphate; $\mu \mathrm{g} \mathrm{L}^{-1}$ ) and frozen until analysis with an auto-analyzer (Metrohm 8000 IC-Plus).

\subsection{CDOM optical properties}

Absorption spectra of CDOM were obtained between 250 and $700 \mathrm{~nm}$ at $1 \mathrm{~nm}$ intervals with a spectrophotometer (UVVIS Shimadzu) using a $5 \mathrm{~cm}$ quartz cuvette and a Milli$\mathrm{Q}$ water sample as blank reference. The absorption spectra of each sample were measured in replicate (standard deviation $<0.01)$. The absorption coefficients $\left(a_{\mathrm{CDOM}}(\lambda) ; \mathrm{m}^{-1}\right)$ were derived from absorbance measurements according to the equation $a_{\mathrm{CDOM}}(\lambda)=2.303 A(\lambda) \mathrm{L}^{-1}$, where $A(\lambda)$ is the absorbance measured at wavelength $\lambda$ and $\mathrm{L}$ is the optical path of the cuvette (in meters). Absorption coefficients were corrected for backscattering by subtracting the value of the coefficient at $700 \mathrm{~nm}$. The absorption coefficient at $254 \mathrm{~nm}$ $\left(a_{\mathrm{CDOM} 254}\right)$ was used as an index of CDOM UV absorption and at $440 \mathrm{~nm}\left(a_{\mathrm{CDOM} 440}\right)$ as a CDOM PAR absorption.

We used a simple exponential curve to model the decrease in absorption with increasing wavelength using the equation (Jerlov, 1968; Bricaud et al., 1981; Stedmon and Markager, 2001): $a_{\mathrm{CDOM}}(\lambda)=a_{\mathrm{CDOM}}(\lambda 0) e^{-S(\lambda-\lambda 0)}+K$, where $a_{\mathrm{CDOM}}$ is the absorption coefficient $\left(\mathrm{m}^{-1}\right), \lambda$ is the wavelength $(\mathrm{nm}), \lambda 0$ is a reference wavelength $(\mathrm{nm}), K$ is a background constant $\left(\mathrm{m}^{-1}\right)$ accounting for scatter in the cuvette and drift of the instrument and $S$ is the spectral slope $\left(\mathrm{nm}^{-1}\right)$ that describes the approximate exponential rate of decreasing absorption with increasing wavelength. Furthermore, we calculated the spectral slope between 275 and $295 \mathrm{~nm}$ $\left(S_{275-295}\right)$ and $350-400 \mathrm{~nm}\left(S_{350-400}\right)$. The slope ratio $\left(S_{\mathrm{R}}\right.$, Helms et al., 2008) was obtained by dividing $S_{275-295} \mathrm{~nm}$ by

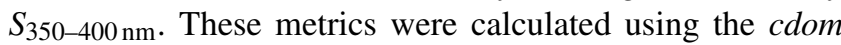
$\mathrm{R}$ package (Massicotte and Markager, 2016). We also calculated $S_{250-450}$ as a proxy to measure changes in the entire spectrum including UV and PAR-absorbing (we limit to $450 \mathrm{~nm}$ because at higher wavelengths the signal-to-noise ratio was high). This metric was further used in the principal component analysis. The specific UV absorbance ( $\left.\mathrm{SUVA}_{254}\right)$ $\left(\mathrm{m}^{2} \mathrm{mg}^{-1} \mathrm{C}\right)$ was calculated by dividing the value of the absorption coefficient at $254 \mathrm{~nm}\left(\mathrm{~m}^{-1}\right)$ by the concentration of DOC $\left(\mathrm{mg} \mathrm{L}^{-1}\right)$ (Weishaar et al., 2003).

\subsection{Data analysis}

The mesocosms were grouped in the figures as follows in order to show the differences between the two different sources of OM (allochthonous versus autochthonous source): the group "OM addition" includes the OM, OMNUT, OMSH 
and OMNUTSH treatments combined. The group "nutrients addition" includes the NUT, OMNUT, NUTSH, OMNUTSH treatments and the group "with shade" include the $\mathrm{SH}, \mathrm{OMSH}, \mathrm{NUTSH}$ and OMNUTSH. The last three groups "without OM addition", "without NUT addition" and "full light" include the remaining four treatments, totaling six different groups (see Table S1 in the Supplement). In this context, the group "OM addition" represents the allochthonous source, while the group "nutrients addition" represents the autochthonous OM source.

The relative changes $(\%)$ of the parameters over time were calculated by dividing the value measured at the end of the experiment by the value at the beginning (day 0 ) of the experiment, after subtracting this result from 1 and multiplying by $100[(1-$ end/start $) \times 100]$. Negative relative change values indicate decrease and positive values indicate increase compared to initial values in the beginning of the experiment.

We performed a three-way ANOVA plus the second-order interactions, in order to verify the effect of each factor (nutrients and $\mathrm{OM}$ additions and shade) on the response variables (quantity ( $a_{\mathrm{CDOM} 254}, a_{\mathrm{CDOM} 440}$ and DOC) and quality (SUVA $_{254}$ and spectral slopes) of DOM and phytoplankton biomass (measured by $\mathrm{Chl} a$ concentration)). We also partitioned the coefficient of determination of each ANOVA in terms of its factors and interactions in order to estimate the relative importance of each driver on the results for DOM optical properties (Lindeman et al., 1980). The interactions that were worth to mention we compute the least-squares means, plus the $95 \%$ confidence interval, for specified factors combinations. All statistical analysis were performed in R software (R Core Team, 2017), plus packages "lsmeans" (Lenth, 2016) and "relaimpo" (Grömping, 2006). A threshold significance level of $5 \%$ was considered.

A principal component analysis (PCA) was carried out using CDOM absorption spectra (with $1 \mathrm{~nm}$ interval between 250 and $450 \mathrm{~nm}$ ) on a $n \times p$ matrix, where $n$ is the number of observations in the dataset $(n=80)$ and $p$ is the wavelength number $(250 \leq p \leq 450)$. The PCA was performed on scaled data (zero mean and unit variance) as suggested by Borcard et al. (2011). This approach was used to summarize absorption spectra (Reader et al., 2015), which are difficult to summarize into a single value observation such as other variables like Chl $a$. Based on the Kaiser-Guttman criterion (Kaiser, 1960), the first two principal components were kept for subsequent analyses. PCA scores of first two axes (PC1 and PC2) were correlated against environmental variables (categorical variables shading, nutrients and $\mathrm{OM}$ additions and the continuous variables Chl $a$, TSM, DOC, $S_{\mathrm{R}}$ and $\mathrm{SUVA}_{254}$ ) using a redundancy analysis (RDA) to help to understand their interpretation. All statistical analyses were performed using R software (R Core Team, 2011).
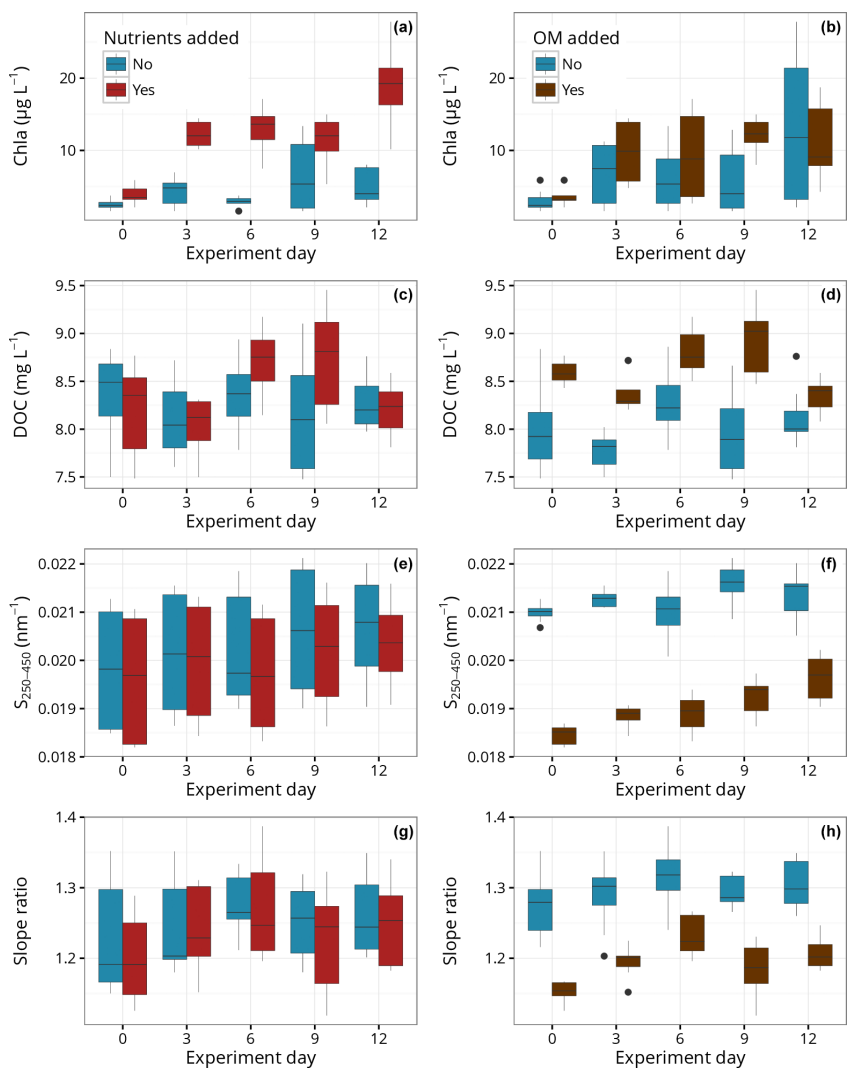

Figure 2. Temporal variation in the mesocosms units with and without nutrients (left column) and organic matter additions (right column) for Chl $a(\mathbf{a}, \mathbf{b})$, DOC (c, d), $S_{250-450}(\mathbf{e}, \mathbf{f})$, and $S_{\mathrm{R}}(\mathbf{g}, \mathbf{h})$ (center line: median; 5th/95th percentiles; $95 \%$ confidence level; black circles: outlier).

\section{Results}

\subsection{Characteristics of the treatments}

The results obtained by three-way analysis of variance (Table 1) showed that Chl $a$ levels were significantly higher for treatments with addition of nutrients (average $11.9 \mu \mathrm{g} \mathrm{L}^{-1}$ ), and also with addition of $\mathrm{OM}$ (average $9.2 \mu \mathrm{g} \mathrm{L}{ }^{-1}$ ) (Fig. 2a-b). Concentrations of DOC and absorption coefficients of $a_{\mathrm{CDOM} 254}$ and $a_{\mathrm{CDOM} 440}$ were significantly higher in all the treatments with addition of OM (averages: DOC, $8.6 \mathrm{mg} \mathrm{L}^{-1} ; a_{\mathrm{CDOM} 254}, 21.9 \mathrm{~m}^{-1} ; a_{\mathrm{CDOM} 440}$, $0.7 \mathrm{~m}^{-1}$ ). Lower $S_{275-295}$ (average $0.02 \mathrm{~nm}^{-1}$ ) and higher SUVA $_{254}$ (average $2.5 \mathrm{~m}^{2} \mathrm{mg}^{-1} \mathrm{C}$ ) were observed also in the treatments with $\mathrm{OM}$ added. Treatments shaded showed lower DOC concentrations (average $8.2 \mathrm{mg} \mathrm{L}^{-1}$ ), higher SUVA $_{254}$ (average $2.4 \mathrm{~m}^{2} \mathrm{mg}^{-1} \mathrm{C}$ ) and lower $S_{275-295}$ (average $0.02 \mathrm{~nm}^{-1}$ ). The results also showed a significant effect for the interaction between nutrients and shade for $a_{\mathrm{CDOM} 254}$ and $a_{\mathrm{CDOM} 440}$ (Table 1 and Figs. S1 and S2 in the Supplement). 
Table 1. Results of the three-way analysis of variance. The coefficient of determination of the analysis of variance partition is represented in the last column by $\% \mathrm{R} 2$.

\begin{tabular}{|c|c|c|c|c|c|c|c|}
\hline Parameters & Source of variation & DF & SS & MS & $\mathrm{F}$ & $\mathrm{P}$ & $\% \mathrm{R} 2$ \\
\hline \multirow{8}{*}{$a_{\mathrm{CDOM} 254}\left(\mathrm{~m}^{-1}\right)$} & $\mathrm{OM}$ & 1 & 419.88 & 419.88 & 1427.44 & $<0.001$ & $93.3 \%$ \\
\hline & NUT & 1 & 6.51 & 6.51 & 22.13 & $<0.001$ & $1.4 \%$ \\
\hline & $\mathrm{SH}$ & 1 & 0.01 & 0.01 & 0.04 & 0.841 & $0.0 \%$ \\
\hline & $\mathrm{OM} \times \mathrm{NUT}$ & 1 & 0.52 & 0.52 & 1.76 & 0.189 & $0.1 \%$ \\
\hline & $\mathrm{OM} \times \mathrm{SH}$ & 1 & 0.47 & 0.47 & 1.59 & 0.211 & $0.1 \%$ \\
\hline & $\mathrm{NUT} \times \mathrm{SH}$ & 1 & 1.31 & 1.31 & 4.47 & 0.038 & $0.3 \%$ \\
\hline & Residuals & 73 & 21.47 & 0.29 & & & $0.0 \%$ \\
\hline & Total & 79 & 450.17 & & & & $95.2 \%$ \\
\hline \multirow[t]{8}{*}{$a_{\mathrm{CDOM} 440}\left(\mathrm{~m}^{-1}\right)$} & $\mathrm{OM}$ & 1 & 1.33 & 1.33 & 230.38 & $<0.001$ & $73.5 \%$ \\
\hline & NUT & 1 & 0.01 & 0.01 & 1.69 & 0.198 & $0.5 \%$ \\
\hline & $\mathrm{SH}$ & 1 & 0.02 & 0.02 & 2.99 & 0.088 & $1.0 \%$ \\
\hline & $\mathrm{OM} \times \mathrm{NUT}$ & 1 & 0.01 & 0.01 & 0.97 & 0.329 & $0.3 \%$ \\
\hline & $\mathrm{OM} \times \mathrm{SH}$ & 1 & 7.37E-07 & $7.37 \mathrm{E}-07$ & $1.28 \mathrm{E}-04$ & 0.991 & $0.0 \%$ \\
\hline & $\mathrm{NUT} \times \mathrm{SH}$ & 1 & 0.03 & 0.03 & 4.37 & 0.040 & $1.4 \%$ \\
\hline & Residuals & 73 & 0.42 & 0.01 & & & $0.0 \%$ \\
\hline & Total & 79 & 1.81 & & & & $76.7 \%$ \\
\hline \multirow[t]{8}{*}{$\mathrm{DOC}\left(\mathrm{mg} \mathrm{L}^{-1}\right)$} & $\mathrm{OM}$ & 1 & 7.07 & 7.07 & 61.63 & $<0.001$ & $42.8 \%$ \\
\hline & NUT & 1 & 0.38 & 0.38 & 3.30 & 0.073 & $2.3 \%$ \\
\hline & $\mathrm{SH}$ & 1 & 0.70 & 0.70 & 6.07 & 0.016 & $4.2 \%$ \\
\hline & $\mathrm{OM} \times \mathrm{NUT}$ & 1 & $1.32 \mathrm{E}-03$ & $1.32 \mathrm{E}-03$ & 0.01 & 0.915 & $0.0 \%$ \\
\hline & $\mathrm{OM} \times \mathrm{SH}$ & 1 & $3.74 \mathrm{E}-04$ & 3.74E-04 & $3.26 \mathrm{E}-03$ & 0.955 & $0.0 \%$ \\
\hline & $\mathrm{NUT} \times \mathrm{SH}$ & 1 & $1.97 \mathrm{E}-03$ & $1.97 \mathrm{E}-03$ & 0.02 & 0.896 & $0.0 \%$ \\
\hline & Residuals & 73 & 8.38 & 0.11 & & & $0.0 \%$ \\
\hline & Total & 79 & 16.53 & & & & $49.3 \%$ \\
\hline \multirow[t]{8}{*}{$\mathrm{SUVA}_{254}\left(\mathrm{~m}^{2} \mathrm{mg}^{-1} \mathrm{C}\right)$} & $\mathrm{OM}$ & 1 & 2.85 & 2.85 & 296.38 & $<0.001$ & $78.0 \%$ \\
\hline & NUT & 1 & 0.02 & 0.02 & 2.37 & 0.128 & $0.7 \%$ \\
\hline & $\mathrm{SH}$ & 1 & 0.05 & 0.05 & 5.60 & 0.021 & $1.4 \%$ \\
\hline & $\mathrm{OM} \times \mathrm{NUT}$ & 1 & 0.01 & 0.01 & 0.98 & 0.325 & $0.3 \%$ \\
\hline & $\mathrm{OM} \times \mathrm{SH}$ & 1 & 0.01 & 0.01 & 0.67 & 0.417 & $0.2 \%$ \\
\hline & $\mathrm{NUT} \times \mathrm{SH}$ & 1 & 0.02 & 0.02 & 1.90 & 0.172 & $0.5 \%$ \\
\hline & Residuals & 72 & 0.69 & 0.01 & & & $0.0 \%$ \\
\hline & Total & 78 & 3.65 & & & & $81.0 \%$ \\
\hline \multirow[t]{8}{*}{$S_{275-295}\left(\mathrm{~nm}^{-1}\right)$} & $\mathrm{OM}$ & 1 & $1.89 \mathrm{E}-04$ & $1.89 \mathrm{E}-04$ & 287.91 & $<0.001$ & $76.4 \%$ \\
\hline & NUT & 1 & $2.00 \mathrm{E}-06$ & $2.00 \mathrm{E}-06$ & 3.05 & 0.085 & $0.8 \%$ \\
\hline & $\mathrm{SH}$ & 1 & 7.93E-06 & 7.93E-06 & 12.08 & 0.001 & $3.2 \%$ \\
\hline & $\mathrm{OM} \times \mathrm{NUT}$ & 1 & 2.95E-09 & 2.95E-09 & $4.50 \mathrm{E}-03$ & 0.947 & $0.0 \%$ \\
\hline & $\mathrm{OM} \times \mathrm{SH}$ & 1 & $3.58 \mathrm{E}-08$ & $3.58 \mathrm{E}-08$ & 0.05 & 0.816 & $0.0 \%$ \\
\hline & $\mathrm{NUT} \times \mathrm{SH}$ & 1 & 4.11E-07 & $4.11 \mathrm{E}-07$ & 0.63 & 0.431 & $0.2 \%$ \\
\hline & Residuals & 73 & 4.79E-05 & $6.56 \mathrm{E}-07$ & & & $0.0 \%$ \\
\hline & Total & 79 & $2.47 \mathrm{E}-04$ & & & & $80.6 \%$ \\
\hline \multirow[t]{8}{*}{ Chl $a\left(\mu \mathrm{g} \mathrm{L}^{-1}\right)$} & $\mathrm{OM}$ & 1 & 92.60 & 92.60 & 4.46 & 0.038 & $3.3 \%$ \\
\hline & NUT & 1 & 1172.94 & 1172.94 & 56.53 & $<0.001$ & $41.4 \%$ \\
\hline & $\mathrm{SH}$ & 1 & 6.61 & 6.61 & 0.32 & 0.574 & $0.2 \%$ \\
\hline & $\mathrm{OM} \times \mathrm{NUT}$ & 1 & 32.24 & 32.24 & 1.55 & 0.217 & $1.1 \%$ \\
\hline & $\mathrm{OM} \times \mathrm{SH}$ & 1 & 12.44 & 12.44 & 0.60 & 0.441 & $0.4 \%$ \\
\hline & $\mathrm{NUT} \times \mathrm{SH}$ & 1 & 0.29 & 0.29 & 0.01 & 0.906 & $0.0 \%$ \\
\hline & Residuals & 73 & 1514.56 & 20.75 & & & $0.0 \%$ \\
\hline & Total & 79 & 2831.67 & & & & $46.5 \%$ \\
\hline
\end{tabular}

OM: organic matter; NUT: nutrients; SH: shade 
The partitioned coefficient of determination for $a_{\mathrm{CDOM} 254}$, $a_{\mathrm{CDOM} 440}, \mathrm{SUVA}_{254}$ and $S_{275-295}$ were very high $(>75 \%)$, indicating that the most important drivers for these variables were included in the experiment. For DOC and Chl $a$ the coefficient of determination showed intermediate values ( $\sim 50 \%)$, indicating that other variables not considered in the experiment also played an important role. The difference between treatments with and without OM played the biggest role in explaining the variation of all response variables evaluated in the experiment, except $\mathrm{Chl} a$. As expected, the difference in nutrients had the biggest effect over Chl $a$ concentrations.

\subsection{Temporal changes in the mesocosms}

Average phytoplankton biomass ( $\mathrm{Chl} a$ ) increased over time only in the treatments with addition of nutrients (from average of 3.9 on day 0 to $19.1 \mu \mathrm{g} \mathrm{L}^{-1}$ on day 12) and OM (from minimum average 3.4 on day 0 to maximum of $12.1 \mu \mathrm{g} \mathrm{L}^{-1}$ on day 9) (Fig. 2a-b). Average DOC increased in the experimental units with added nutrients until day 9 (maximum $8.7 \mathrm{mg} \mathrm{L}^{-1}$ ). In treatments with addition of OM, DOC was higher as expected with a minimum of $8.3 \mathrm{mg} \mathrm{L}^{-1}$ at day 3 and maximum of $8.9 \mathrm{mg} \mathrm{L}^{-1}$ on day 9 , while in the treatments without addition of OM the DOC had a maximum of $8.2 \mathrm{mg} \mathrm{L}^{-1}$ on day 6 (Fig. $2 \mathrm{c}-$ d). $S_{250-450}$ and slope ratio $\left(S_{\mathrm{R}}\right)$ had the same pattern in the treatments with and without nutrients addition, but they decreased consistently in treatments with OM addition (Fig. 2e-h).

The relative changes in CDOM absorption along the spectral range were different for each sampling day (Fig. 3a-e). On the initial day, only treatments with and without addition of OM had distinct absorption curves, especially in the UV range below $400 \mathrm{~nm}$, and the absorption spectra for each treatment group on day 0 are shown in Fig. 3a. To evaluate treatment effects we determined the change in light absorption spectra for the other sampling days relative to the initial day (Fig. 3b-e). On day 3, treatments with and without nutrients added were quite similar, while those with and without OM and with and without shading showed opposing changes. Loss of absorption occurred only in treatments with full light (less than $5 \%$ between 300 and $420 \mathrm{~nm}$ ) and in those without OM addition (the loss of absorption increased with the increase in wavelength) (Fig. 3b). On day 6 all treatments showed an increased absorption especially after $350 \mathrm{~nm}$ (higher increase with shade: $\sim 40 \%$ at $450 \mathrm{~nm}$ ), except the treatments with full light that still had a loss of absorption (Fig. 3c). On day 9 and 12, all treatments had a loss of CDOM absorption with increasing wavelengths, especially for the full light treatment (Fig. 3d-e).

The concentrations of DIP and DIN $\left(\mu \mathrm{g} \mathrm{L}^{-1}\right)$ and the molar ratio between them (DIN:DIP) were higher in treatments with added nutrients as expected (Fig. $4 \mathrm{a}-\mathrm{c}$ ). In the treatments without nutrients addition, DIP concentrations ranged between 3 and $9 \mu \mathrm{gL}^{-1}$ and DIN between 1.7 and
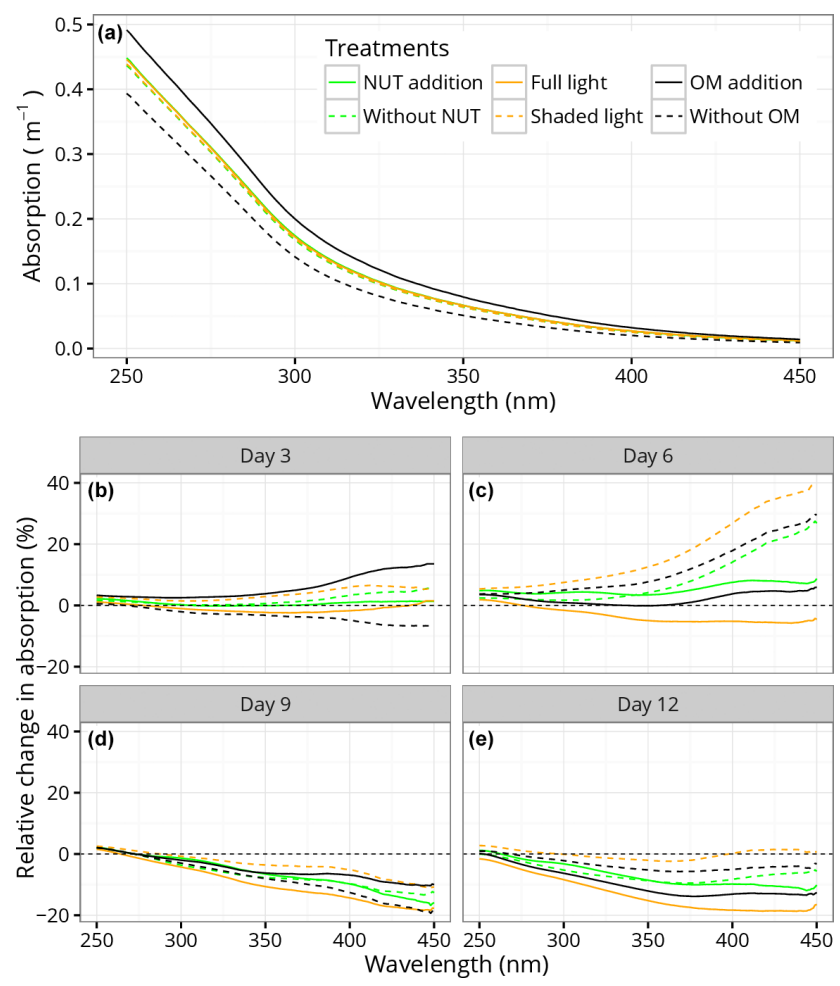

Figure 3. Spectral absorption curves of CDOM in the different mesocosms units for the initial day (a) and the relative changes for each sampling day compared with the initial day (day 3: b; day 6: c; day 9: d; day 12: e).

$100.4 \mu \mathrm{g} \mathrm{L}^{-1}$, with DIN : DIP ratios ranging between 7.6 (day 12) and 21.3 (day 0) and below 13.9 after day 3, suggesting that phytoplankton community were mostly limited by nitrogen in these treatments (Reynolds, 1999). All the dissolved nutrients decreased over the course of the experiment in all treatments with nutrients addition (DIP decreased from an average of 153 to $59 \mu \mathrm{g} \mathrm{L}^{-1}$ and DIN from 2600 to $400 \mu \mathrm{g} \mathrm{L}^{-1}$ ). The DIN : DIP molar ratio ranged from 55.3 (day 3) to 12.2 (day 12) in the mesocosms with addition of nutrients.

\subsection{Principal component analysis results}

The first principal component of the redundancy analysis (Fig. 5a) was mostly associated with availability of OM. Samples presenting high scores on the first principal component furthermore tended to have high values of DOC and SUVA $_{254}$ but low values of $S_{\mathrm{R}}$. High scores in the second principal component correlated positively with Chl $a$, nutrients and TSM and negatively with shading.

Exploration of spectral PCA loadings (Fig. 5b-c) revealed that principal component 1 (PC1) had the strongest effect on the shape of CDOM absorbance between 300 and $400 \mathrm{~nm}$. Principal component 2 (PC2) loadings showed a quasi-linear decrease with increasing wavelength suggesting that phyto- 

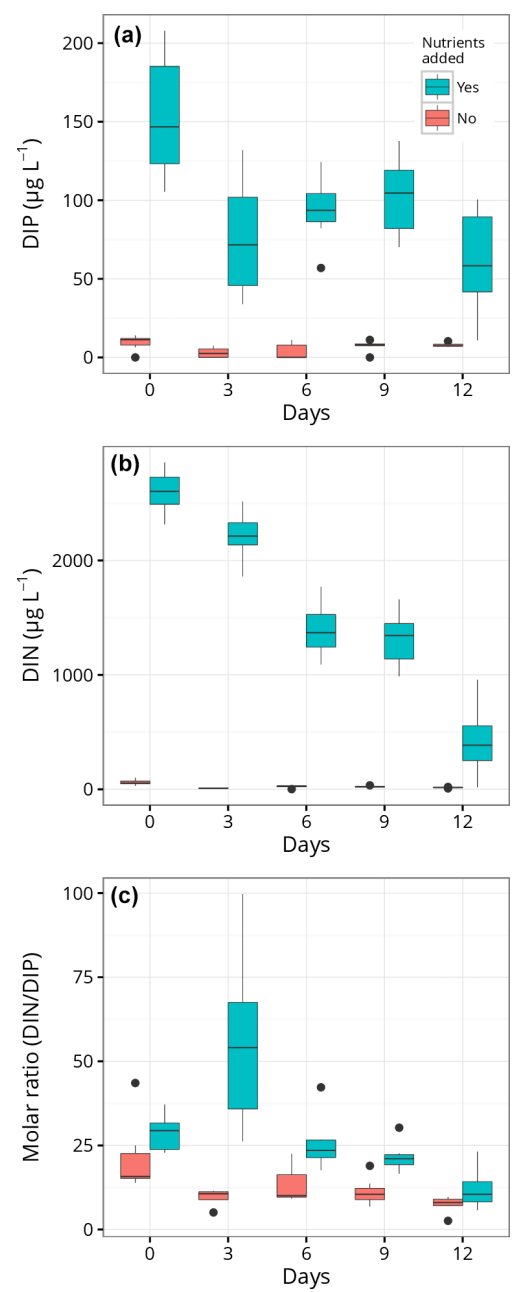

Figure 4. Temporal variation in the mesocosms units with and without nutrients additions for dissolved inorganic phosphorusDIP (a), dissolved inorganic nitrogen-DIN (b) and the molar ratio DIN / DIP (c) (center line: median; 5th/95th percentiles; $95 \%$ confidence level; black circles: outlier).

plankton enrichment had a stronger effect at lower wavelengths. Furthermore, loading values were negative after $\sim 340 \mathrm{~nm}$, indicating that phytoplankton was on average lowering CDOM absorption after this threshold. Based on the redundancy analysis, $\mathrm{PC} 1$ was renamed "allochthonous carbon enrichment", whereas PC2 was renamed "autochthonous carbon enrichment".

\section{Discussion}

\subsection{Nutrients, allochthonous matter and shade responses in DOM and Chl $a$}

Our results showed a pronounced sensitivity of the composition of DOM in a tropical lake on artificial alterations in environmental parameters such as light and nutrient avail- ability and allochthonous matter inputs. As expected, the addition of allochthonous matter results in a DOM pool which is dominated by more aromatic carbon with higher molecular weight (Bertilsson and Tranvik, 2000; Benner, 2002) and lower spectral slopes (Helms et al., 2008; Fig. 2f, h). Addition of nutrients also affected DOM quantity and quality related to autochthonous production by phytoplankton growth, which can be an important source of DOM (Zhang et al., 2009, 2013; Brandão et al., 2016). In the treatments without addition of nutrients, the phytoplankton community was limited by nitrogen since the beginning of the experiment (DIN $<100 \mu \mathrm{g} \mathrm{L}^{-1}$; Reynolds, 1999). The DIN : DIP molar ratio in these treatments indicates that nitrogen was consumed very fast and was limited after day 3 (ratio below 13.9; Hecky and Kilham, 1988). With the addition of nutrients, the concentrations of DIN and DIP were higher than considered to be limiting (Reynolds, 1999). However, the molar ratio (DIN : DIP) was always higher than $10: 1$, suggesting limitation by phosphorus (molar ratios between 21.3 and 55.3) over the days of experiment and only becoming limited by nitrogen following day 12 (molar ratio 12.2) (Hecky and Kilham, 1988). Moreover, these apparent limitations did not restrict the phytoplankton growth in mesocosms with addition of nutrients. Mesocosms which did not receive nutrients but which received allochthonous OM also experienced an increase in Chl $a$ after 3 days (Fig. 2b). The light attenuation caused by enhanced light absorption from added allochthonous OM (Kirk, 1994) favored growth of phytoplankton by reducing photoinhibition (Brighenti et al., 2018), commonly occurring during summer in Lake Carioca (Brighenti et al., 2015). The increase in phytoplankton in these treatments therefore suggests that algal growth was stimulated by a combination of increases in nutrient availability due to degradation of the OM added (Hessen and Tranvik, 1998) and possibly due to release of labile substances derived from photodegradation (Cory et al., 2014). Our study shows that in addition to providing a source of nutrients, allochthonous inputs to tropical lakes may strongly affect the seasonal dynamics of phytoplankton by reducing of photoinhibition through elevated UV absorption. These results corroborates previous studies that where lake ecosystem metabolism are indirectly controlled by terrestrial material during periods of higher rainfall (Brighenti et al., 2015; Brandão et al., 2016).

Although additions of allochthonous $\mathrm{OM}$ and nutrients both contributed to higher DOC concentrations, divergent effects of these additions were evident in the quality of carbon assessed by optical indices $\left(S_{250-450}\right.$ and $\left.S_{\mathrm{R}}\right) . S_{250-450}$ and $S_{\mathrm{R}}$ decreased significantly after addition of allochthonous OM (Fig. 2f, h). The decrease in the slope $S_{250-450}$ was related to the increase in a higher molecular weight carbon, which lowered the values of $S_{275-295}$ and consequently of $S_{\mathrm{R}}$ (Helms et al., 2008). This shows that small changes in the amount and quality of allochthonous contribution to lakes, due to changes in either rainfall or land use change, may cause considerable changes in the optical quality of the aquatic sys- 

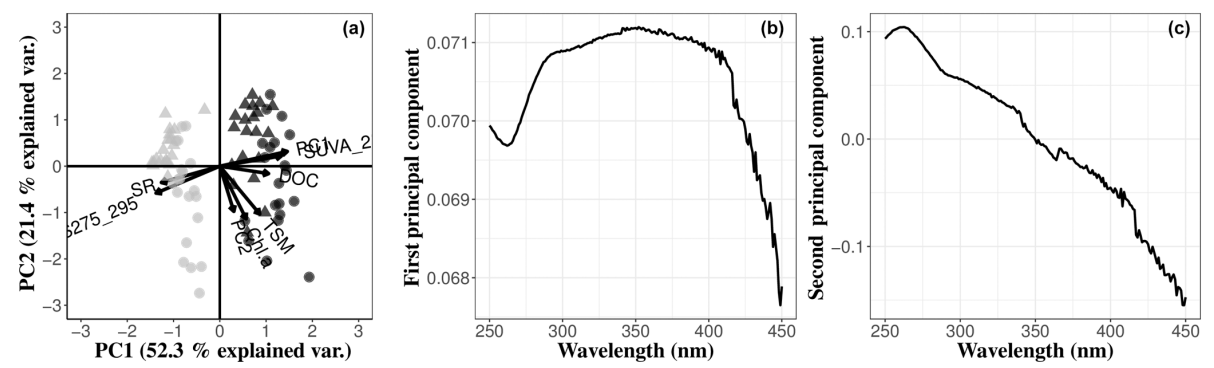

Figure 5. Results of redundancy analysis (RDA) (a) and the first two principal components obtained from PCA, PC1 (b) and PC2 (c), plotted against wavelengths. Gray symbols represent the treatments without organic matter addition and the black ones those with organic matter. Triangles represent treatments without added nutrients and circles those with nutrients addition.

tems, as alterations in the water transparency by changes in the UV and PAR absorbing. This corroborates other studies that claim that tropical lakes are highly sensitive to climate changes (Adrian et al., 2009), causing serious modifications of lake physical and chemical conditions (Jeppesen et al., 2014), with ultimate effects on lake productivity for example (O'Reilly et al., 2003).

Addition of nutrients, however, had little effect on these metrics, which we interpreted as a consequence of autochthonous production of DOM. This is likely because these indices are derived from slope intervals in the ultraviolet range $(250-400 \mathrm{~nm})$ known to be influenced by carbon with higher molecular weight and aromatic compounds capable of absorbing energy at shorter wavelengths (Bertilsson and Tranvik, 2000; Benner, 2002; Helms et al., 2008). Moreover, nutrient additions only increased $a_{\mathrm{CDOM} 254}$ and $a_{\mathrm{CDOM} 440}$ in the shaded treatments (Figs. S1 and S2), suggesting an increase in PAR and UV absorbance due to less photodegradation and less photoinhibition for the phytoplankton in the shaded treatments.

Manipulations of nutrients, allochthonous OM and light availability caused distinctive changes in the spectral curves of CDOM over the sampling days (Fig. 3). Several studies have shown that aromatic organic carbon, typically of terrestrial origin, has relatively higher absorption in the ultraviolet range (Bertilsson and Tranvik, 2000; Benner, 2002; Helms et al., 2008). This can explain the initial (day 0) effects of allochthonous OM addition on elevated CDOM absorption primarily below $350 \mathrm{~nm}$ (Fig. 3a). We interpret the following increase in the CDOM absorption (days 3 and 6, especially above $350 \mathrm{~nm}$ ) for most treatments to result from autochthonous DOM related to phytoplankton growth, as increases in absorption in the PAR range (Fig. 3b-c) are known to be related to increases in carbon of simple structures from algal origin (Amon and Benner, 1994; McKnight et al., 1994; Benner, 2002; Helms et al., 2008). After day 9 (Fig. 3de) the absorption loss was larger than the gain by the autochthonous production in all treatments, and such spectral changes with larger absorption decreases in higher wavelengths are likely due to biological degradation of CDOM
(Asmala et al., 2014). However, it is important to note that the relative changes in the spectral curves shown in Fig. 3 reflect the net change from two counteracting processes: autochthonous production and loss of absorption by photodegradation and/or biodegradation. Treatments that were exposed to full light (orange solid lines) and the shaded treatments (orange dashed lines) presented notable differences between each other in the relative changes in the CDOM absorption spectrum. This corroborates our results of the more aromatic carbon with larger molecular size (higher $\mathrm{SUVA}_{254}$ and lower $S_{275-295}$, Table 1) observed in shaded mesocosms, suggesting lower photodegradation in these units.

\subsection{Effect of allochthonous and autochthonous DOM on CDOM spectra}

The PCA and redundancy analysis showed that the increase in allochthonous $\mathrm{OM}$ increased absorption between the wavelengths 300 and $400 \mathrm{~nm}$ (PC1, Fig. 5b). Several studies have shown that photodegradation is more pronounced at shorter wavelengths (300-400 nm) due to absorption of aromatic carbon compounds (Helms et al., 2008, 2013) typically related to degradation of either terrestrial vegetation (Bertilsson and Tranvik, 2000; Benner, 2002; Helms et al., 2008) or aquatic macrophytes (Catalán et al., 2013). We noticed a decrease in the CDOM absorption below $300 \mathrm{~nm}$, suggesting a greater degradation by photodegradation in these compounds from allochthonous origin affecting the absorption at shorter wavelengths and increasing the absorption between 300 and $400 \mathrm{~nm}$. In contrast, the increase in autochthonous OM from the phytoplankton growth is likely to have resulted in an increase in absorption in the UV range and a loss of absorption at wavelengths beyond $350 \mathrm{~nm}$ (PC2; Fig. 5c). The loss of absorption above $350 \mathrm{~nm}$ indicates degradation by microorganisms which have a greater impact on the PAR absorption. Substances that absorb in this range are typically non-aromatic compounds originating from algal sources with high lability for bacterial degradation (Baines and Pace, 1990; Berggren et al., 2009). 


\section{Conclusions}

Additions of terrestrial OM and inorganic nutrients to a tropical lake mesocosm caused fast changes in the production and transformation of OM pools as well as distinct changes in the absorption spectra of CDOM. Increased production of autochthonous OM caused an increase in CDOM absorption in the UV range. However, we found that CDOM absorption was reduced in the PAR range, indicating bacterial degradation of highly labile algal material (Baines and Pace, 1990; Berggren et al., 2009). In contrast, the additions of allochthonous OM caused increased absorption of CDOM, especially between 300 and $400 \mathrm{~nm}$. $S_{250-450}$ was an effective tool to evaluate the spectral changes in general from short to long wavelengths, not restricting spectrum ranges where we can only perceive changes in some regions of UV absorption $\left(S_{275-295}, S_{350-400}\right)$. Although the non-shaded treatments showed apparent effects of photodegradation, changes in CDOM absorption curves after day 9 suggest that biodegradation was overall responsible for the largest percentage of OM degradation in these experiments. The $50 \%$ reduction of sunlight in some mesocosms accordingly had minor effects on overall changes in OM concentration, but the effect of shading was significant for OM quality and was important for the effect of nutrients on the absorbance at 254 and $440 \mathrm{~nm}$.

\section{Implications}

Our experiment adds knowledge on how input of terrestrial OM and nutrients, related to water column mixing and rains, influence carbon cycling in tropical lakes (Brighenti et al., 2015; Brandão et al., 2016). Even small inputs of allochthonous OM can have much larger effects on the spectral characteristics on the lake CDOM, compared to large production of autochthonous OM. Local changes in land use, through replacement of Atlantic Forest, will likely alter the spectral light quality. Such changes can affect a range of chemical (concentration and quality of DOM), physical (e.g upper layer mixing due to changes in the absorption of PAR and UV radiation; Read and Rose, 2013) and biological conditions (vertical distribution and productivity of aquatic organisms; Gagliardi et al., 2018). Recent reductions in regional precipitation (Roland et al., 2012) and observed lake volumes provide further evidence of a strong control by allochthonous $\mathrm{OM}$ on the physical, chemical and biological conditions in the Rio Doce region. As drafts are expected to become more common (IPCC, 2013), allochthonous OM will likely have an increasing control on aquatic metabolism, DOM dynamics and water transparency in these tropical lakes (Gagliardi, 2015; Brighenti et al., 2015; Brandão, 2016). These impacts will certainly alter the water quality for consumption and for water use in the economic activities in the region, with ultimate effects on regional carbon cycling.
Data availability. The data used in this research are being prepared to be published in the Global Biodiversity Information Facility (www.gbif.org, last access: 5 December 2017) repository. In addition to the data, metadata will also be provided.

\section{The Supplement related to this article is available online at https://doi.org/10.5194/bg-15-2931-2018-supplement.}

Author contributions. LPMB designed the experiment and participated in the field work, laboratory analysis and writing the manuscript.

LSB designed the experiment, participated in the field work and laboratory analysis, and reviewed the manuscript.

PAS designed the experiment and participated in the field work, writing and revision of the manuscript.

EA participated in the writing and revision of the manuscript.

PM participated in the writing and revision of the manuscript and the statistical analyses.

DT participated in the field work and revision of the manuscript.

FARB designed the experiment and participated in the field work, and revision of the manuscript.

DP participated in the statistical analyses, creating figures and revision of the manuscript.

JFBN designed the experiment and participated in the field work, writing and revision of the manuscript.

Competing interests. The authors declare that they have no conflict of interest.

Acknowledgements. This study was supported by the project Carbon Cycling in Lakes (COCLAKE - CAPES Proc. no. 88881.030499/2013-01) and the BONUS COCOA project (grant agreement 2112932-1), funded jointly by the EU and Danish Research Council. We also thank the Conselho Nacional de Desenvolvimento Científico e Tecnológico (CNPq) and Coordenação de Aperfeiçoamento de Pessoal de Nível Superior (CAPES) for financial support, scholarship and opportunity for the Science without Borders program and the Fundação de Amparo à Pesquisa do Estado de Minas Gerais (FAPEMIG). We would like to thank Gustavo Turci, Ralph Thomé, Patrícia Ferreira and Marcelo Ávila for field support and Marcelo Costa for nutrient analysis.

Edited by: Florian Wittmann

Reviewed by: three anonymous referees

\section{References}

Aarnos, H., Ylöstalo, P., and Vähätalo, A. V.: Seasonal phototransformation of dissolved organic matter to ammonium, dissolved inorganic carbon, and labile substrates supporting bacterial biomass across the Baltic Sea, J. Geophys. Res.-Biogeo., G01004, https://doi.org/10.1029/2010JG001633, 2012. 
Adrian, R., O’Reilly, C. M., Zagarese, H., Baines, S. B., Hessen, D. O., Keller, W., Livingstone, D. M., Sommaruga, R., Straile, D., Van Donk, E., Weyhenmeyer, G. A., and Winder, M.: Lakes as sentinels of climate change, Limnol. Oceanogr., 54, 2283-2297, 2009

Amado, A. M., Farjalla, V. F., Esteves, F. A., Bozelli, R. L., Roland, F., and Enrich-Prast, A.: Complementary pathways of dissolved organic carbon removal pathways in clear-water Amazonian ecosystems: photochemical degradation and bacterial uptake, FEMS Microbiol. Ecol., 56, 8-17, 2006.

Amon, R. M. W. and Benner, R.: Rapid cycling of high molecular weight dissolved organic matter in the ocean, Nature, 369, 549552, 1994.

Anesio, A. M. and Granéli, W.: Increased photoreactivity of DOC by acidification: implication for carbon cycle in humic lakes, Limnol. Oceanogr., 48, 735-744, 2003.

APHA: Standard Methods for the Examination of Water and Wastewater, American Public Health Association, American Water Works Association, Water Environmental Federation, 20th Edn., Washington, DC, 1998.

Asmala, E., Autio, R., Kaartokallio, H., Pitkänen, L., Stedmon, C. A., and Thomas, D. N.: Bioavailability of riverine dissolved organic matter in three Baltic Sea estuaries and the effect of catchment land use, Biogeosciences, 10, 6969-6986, https://doi.org/10.5194/bg-10-6969-2013, 2013.

Asmala, E., Autio, R., Kaartokallio, H., Stedmon, C. A., and Thomas, D. N.: Processing of humic-rich riverine dissolved organic matter by estuarine bacteria: effects of predegradation and inorganic nutrients, Aquat. Sci., 76, 451-463, https://doi.org/10.1007/s00027-014-0346-7, 2014.

Attermeyer, K., Tittel, J., Allgaier, M., Frindte, K., Wurzbacher, C., Hilt, S., Kamjunke, N., and Grossart, H. P.: Effects of Light and Autochthonous Carbon Additions on Microbial Turnover of Allochthonous Organic Carbon and Community composition, Microb. Ecol., 69, 361-371, https://doi.org/10.1007/s00248-0140549-4, 2015.

Azam, F., Fenchel, T., Fiel, J. G., Gray, J. S., Meyer-Rell, L. A., and Thingstad, F.: The ecological role of water-column microbes in the sea, Mar. Ecol.-Prog. Ser., 19, 257-263, 1983.

Baines, S. B. and Pace, M. L.: The production of dissolved organic matter by phytoplankton and its importance to bacteria: Patterns across marine and freshwater systems, Limnol. Oceanogr., 36, 1078-1090, 1990.

Benner, R.: Chemical composition and reactivity, in: Biogeochemistry of marine dissolved organic matter, edited by: Hansell, D. A. and Carlson, C. A., Academic Press, London, 59-90, 2002.

Berggren, M., Laudon, H., and Jansson, M.: Aging of allochthonous organic carbon regulates bacterial production in unproductive boreal lakes, Limnol. Oceanogr., 54, 1333-1342, 2009.

Bertilsson, S. and Tranvik, L. J.: Photochemical transformation of dissolved organic matter in lakes, Limnol. Oceanogr., 45, 753762, 2000

Bezerra-Neto, J. F., Barbosa, P. M., and Barbosa, F. A. R.: Temporal variation of attenuation of the visible radiation in four lakes of Parque Estadual do Rio Doce (PERD), Minas Gerais, Brasil, Acta Limnol. Bras., 18, 39-46, 2006.

Bezerra-Neto, J. F., Brighenti, L. S., and Pinto-Coelho, R. M.: A new morphometric study of Carioca Lake, Parque Estadual do
Rio Doce (PERD), Minas Gerais State, Brazil, Acta Sci. Biol., 32, 49-54, 2010.

Bittar, T. B., Vieira, A. A. H., Stubbins, A., and Mopper, K.: Competition between photochemical and biological degradation of dissolved organic matter from the cyanobacteria Microcystis aeruginosa, Limnol. Oceanogr., 60, 1172-1194, https://doi.org/10.1002/lno.10090, 2015.

Borcard, D., Gillet, F., and Legendre, P.: Numerical Ecology with R. New York, NY, Springer New York, https://doi.org/10.1007/9781-4419-7976-6, 2011.

Boreen, A. L., Edhlund, B. L., Cotner, J. B., and McNeill, K.: Indirect photodegradation of dissolved free amino acids: the contribution of singlet oxygen and the differential reactivity of DOM from various sources, Environ. Sci. Technol., 42, 5492-5498, 2008.

Brandão, L. P. M.: Caracterização e importância da matéria orgânica dissolvida em ecossistemas aquáticos tropicais. Doctorate thesis. Universidade Federal de Minas Gerais, Belo Horizonte, Minas Gerais, Brasil, 147 pp., 2016.

Brandão, L. P. M., Staehr, P. A., and Bezerra-Neto, J. F.: Seasonal changes in optical properties of two contrasting tropical freshwater systems, J. Limnol., 75, 508-519, https://doi.org/10.4081/jlimnol.2016.1359, 2016

Bricaud, A., Morel, A., and Prieur, L.: Absorption by Dissolved Organic Matter of the Sea (Yellow Substance) in the UV and Visible Domains, Limnol. Oceanogr., 26, 43-53, https://doi.org/10.4319/lo.1981.26.1.0043, 1981.

Brighenti, L. S.: Uso de sensores de alta frequência para estimativas contínuas de metabolismo e monitoramento em lagos tropicais, Tese de doutorado, Universidade Federal de Minas Gerais, Belo Horizonte, Minas Gerais, Brasil, 2014.

Brighenti, L. S., Staehr, P. A., Gagliardi, L. M., Brandão, L. P. M., Elias, E. C., Mello, N. A. S. T., Barbosa, F. A. R., and BezerraNeto, J. F.: Seasonal changes in metabolic rates of two tropical lakes in the atlantic forest of Brazil, Ecosystems, 18, 589-604, https://doi.org/10.1007/s10021-015-9851-3, 2015.

Brighenti, L. S., Staehr, P. A., Brandão, L. P. M., Barbosa, F. A. R., and Bezerra-Neto, J. F.: Importance of nutrients, organic matter and light availability on epilimnetic metabolic rates in a mesotrophic tropical lake, Freshwater Biol., https://doi.org/10.1111/fwb.13123, 2018.

Catalán, N., Obrador, B., Felip, M., and Pretus, J. L.: Higher reactivity of allochthonous vs. autochthonous DOC sources in a shallow lake, Aquat. Sci., 75, 581-593, https://doi.org/10.1007/s00027013-0302-y, 2013.

Cory, R. M., Ward, C. P., Crump, B. C., and Kling, G. W.: Sunlight controls water column processing of carbon in artic fresh waters, Science, 345, 925-928, https://doi.org/10.1126/science.1253119, 2014.

Farjalla, V. F., Faria, B. M., and Esteves, F. A.: The relationship between DOC and planktonic bacteria in tropical coastal lagoons, Arch. Hydrobiol., 156, 97-119, https://doi.org/10.1127/00039136/2002/0156-0097, 2002.

Farjalla, V. F., Marinho, C. C., Faria, B. M., Amado, A. M., Esteves, F. A., Bozelli, R. L., and Giroldo, D.: Synergy of fresh and accumulated organic matter to bacterial growth, Microb. Ecol., 57, 657-666, https://doi.org/10.1007/s00248-008-9466-8, 2009.

Fonte, E. S., Amado, A. M., Meirelles-Pereira, F., Esteves, F. A., Rosado, A. S., and Farjalla, V. F.: The combination 
of different carbon sources enhances bacterial growth efficiency in aquatic ecosystems, Microb. Ecol., 66, 871-878, https://doi.org/10.1007/s00248-013-0277-1, 2013.

Gagliardi, L. M.: Metabolismo de lagos tropicais: efeito das alterações climáticas sazonais, morfometria dos lagos e característica de suas bacias, Doctorate thesis, Universidade Federal de Minas Gerais, Belo Horizonte, Minas Gerais, Brasil, 122 pp., 2015.

Grömping U.: Relative Importance for Linear Regression in R: The Package relaimpo, J. Stat. Softw., 17, 1-27, 2006.

Guillemette, F. and Del Giorgio, P. A.: Simultaneous consumption and production of fluorescent dissolved organic matter by lake bacterioplankton, Environ. Microbiol., 14, 1432-1443, 2012.

Hecky, R. E. and Kilham, P.: Nutrient limitation of phytoplankton in freshwater and marine environments: a review of recent evidence on the effects of enrichment, Limnol. Oceanogr., 33, 196-822, 1988.

Hedges, J. I.: Global biogeochemical cycles: progress and problems, Mar. Chem., 39, 67-93, 1992.

Helms, J. R., Stubbins, A., Ritchie, J. D., Minor, E. C., Kieber, D. J., and Mopper, K.: Absorption spectral slopes and slope ratios as indicators of molecular weight, source and photobleaching of chromophoric dissolved organic matter, Limnol. Oceanogr., 53, 955-969, 2008.

Helms, J. R., Stubbins, A., Michael Perdue, E., Green, N. W., Chen, H., and Mopper, K.: Photochemical bleaching of oceanic dissolved organic matter and its effect on absorption spectral slope and fluorescence, Mar. Chem., 155, 81-91, 2013.

Hessen, D. O. and Tranvik, L. J. (Eds.): Aquatic humic substances: ecology and biogeochemistry, Springer-Verlag, Berlin, 1998.

Hopkinson, C. S., Buffam, I., Hobbie, J., Vallino, J., Perdue, M., Eversmeyer, B., Prahl, F., Covert, J., Hodson, R., Moran, M. A., Smith, E., Baross, J., Crump, B., Findlay, S., and Foreman, K.: Terrestrial inputs of organic matter to coastal ecosystems: an intercomparison of chemical characteristics and bioavailability, Biogeochemistry, 43, 211-234, 1998.

Intergovernmental Panel on Climate Change: IPCC 2013: Summary for policymakers: Climate change 2013 - the physical science basis, edited by: Stocker, T. F., Qin, D., Plattner, G. K., Tignor, M., Allen, S. K., Boschung, J., Nauels A., Xia, Y., Bex, V., and Midgley, P. M., Working Group 1 contribution to the IPCC fifth assessment report of the Intergovernmental Panel on Climate Change, Cambridge University Press, Cambridge, United Kingdom and New York, NY, USA, 1-27, 2013.

Jeppesen, E. M., Meerhoff, M., Davidson, T. A., Trolle, D., Søndergaard, M., Lauridsen, T. L., Beklioglu, M., Brucet, S., Volta, P., González-Bergonzoni, I., and Nielsen, A.: Climate change impacts on lakes: an integrated ecological perspective based on a multi-faceted approach, with special focus on shallow lakes, J. Limnol., 73, 88-111, https://doi.org/10.4081/jlimnol.2014.844, 2014.

Jerlov, N. G.: Optical Oceanography, Elsevier Publishing Company, New York, 1968.

Johannessen, S. C., Peña, M. A., and Quenneville, M. L.: Photochemical production of carbon dioxide during a coastal phytoplankton bloom, Estuar. Coast. Shelf S., 73, 236-242, 2007.

Kaiser, H. F.: The Application of Electronic Computers to Factor Analysis, Educ. Psychol. Meas., 20, 141-151, https://doi.org/10.1177/001316446002000116, 1960.
Kieber, D. J., McDaniel, J. A., and Mopper, K.: Photochemical source of biological substrates in seawater: implications for carbon cycling, Nature, 341, 637-639, 1989.

Kieber, R. J., Whitehead, R. F., and Skrabal, S. A.: Photochemical production of dissolved organic carbon from resuspended sediments, Limnol. Oceanogr., 51, 2187-2195, 2006.

Kirk, J. T. O.: Light and Photosynthesis in Aquatic Ecosystems, 2nd Edn., Cambridge University Press, Cambridge, 509 pp., 1994.

Kritzberg, E. S., Cole, J. J., Pace, M. L., Granéli, W., and Bade, D. L.: Autochthonous versus allochthonous carbon sources of bacteria: results from whole-lake ${ }^{13} \mathrm{C}$ addition experiments, Limnol. Oceanogr., 49, 588-596, 2004.

Lean, D. R. S. and Pick, F. R.: Photosynthetic response of lake plankton to nutrient enrichment: A test for nutrient limitation, Limnol. Oceanogr., 26, 1001-1019, 1981.

Lenth, R.: Least-squares means: The R package lsmeans, J. Stat. Softw., 69, 1-33, 2016.

Lindell, M. J., Granéli, W., and Bertilson, S.: Seasonal photoreactivity of dissolved organic matter from lakes with contrasting humic content, Can. J. Fish. Aquat. Sci., 57, 875-885, 2000.

Lindeman, R. H., Merenda, P. F., and Gold, R. Z.: Introduction to Bivariate and Multivariate Analysis, Glenview, IL, edited by: Foresman, S., Michigan University, 444 pp., 1980.

Lønborg, C., Álvarez-Salgado, X. A., Davidson, K., MartínezGarcía, S., and Teira, E.: Assessing the microbial bioavailability and degradation rate constants of dissolved organic matter by fluorescence spectroscopy in the coastal upwelling system of the Ría de Vigo, Mar. Chem., 119, 121-129, 2010.

Maillard, P., Pivari, M. O., and Luis, C. H. P.: Remote Sensing for Mapping and Monitoring Wetlands and Small Lakes in Southeast Brazil, Remote Sensing of Planet Earth, edited by: Chemin, Y., InTech, 2012.

Marotta, H., Duarte, C. M., Pinho, L., and Enrich-Prast, A.: Rainfall leads to increased $p \mathrm{CO}_{2}$ in Brazilian coastal lakes, Biogeosciences, 7, 1607-1614, https://doi.org/10.5194/bg-7-16072010, 2010.

Massicotte, P. and Markager, S.: Using a Gaussian decomposition approach to model absorption spectra of chromophoric dissolved organic matter, Mar. Chem. 180, 24-32, https://doi.org/10.1016/j.marchem.2016.01.008, 2016.

McKnight, D. M., Andrew, E. D., Aiken, G. R., and Spaulding, S. A.: Aquatic fulvic acids in algal rich Antarctic ponds, Limnol. Oceanogr., 39, 1972-1979, 1994.

Miller, C., Gordon, K. G., Kieber, R. J., Willey, J. D., and Seaton, P. J.: Chemical characteristics of chromophoric dissolved organic matter in rainwater, Atmos. Environ., 43, 2497-2502, 2009.

Miller, W. L., Moran, M. A., Sheldon, W. M., Zepp, R. G., and Opsahl, S.: Determination of apparent quantum yield spectra for the formation of biologically labile photoproducts, Limnol. Oceanogr., 47, 343-352, 2002.

Mopper, K., Kieber, D. J., and Stubbins, A.: Marine photochemistry: Processes and impacts, in: Biogeochemistry of Marine Dissolved Organic Matter, 2nd Edn., edited by: Hansell, D. A. and Carlson, C. A., Elsevier, 389-450, https://doi.org/10.1016/B9780-12-405940-5.00008-X, 2015.

Myers, N., Mittermeier, R. A., Mittermeier, C. G., Fonseca, G. A. B., and Kent, J.: Biodiversity hotspots for conservation priorities, Nature, 403, 853-858, https://doi.org/10.1038/35002501, 2000. 
O’Reilly, C. M., Alin, S. R., Plisnier, P. D., Cohen, A. S., and McKee, B. A.: Climate change decreases aquatic ecosystem productivity of Lake Tanganyika, Africa, Nature, 424, 766-768, 2003.

Petrucio, M. M., Barbosa, F. A. R., and Furtado, A. L. S.: Bacterioplankton and phytoplankton production in seven lakes in the middle Rio Doce basin, south-east Brazil, Limnologica, 36, 192203, 2006

Pinheiro, M. H. O., Carvalho, L. N., Arruda, R., and Guilherme, F. A. G.: Consequences of suppressing natural vegetation in drainage areas for freshwater ecosystem conservation: considerations on the new "Brazilian forest code", Acta Bot. Brasilica, 29, 262-269, https://doi.org/10.1590/0102-33062014abb0031, 2015.

R Core Team: R: A Language and Environment for Statistical Computing, available at: https://www.R-project.org/, last access: 11 November 2017.

Read, J. S. and Rose, K. C.: Physical responses of small temperate lakes to variation in dissolved organic carbon concentrations, Limnol. Oceanogr., 58, 921-931, 2013.

Reader, H. E., Stedmon, C. A., Nielsen, N., and Kritzberg, E.: Mass and UV-visible spectral fingerprints of dissolved organic matter: sources and reactivity, Frontiers in Marine Science, 2, 88, https://doi.org/10.3389/fmars.2015.00088, 2015.

Reynolds, C. S.: Non-determinism to probability, or N:P in the community ecology of phytoplankton, Arch. Hydrobiol., 146, 23-35, 1999.

Reynolds, C. S.: Hydrodynamics and mixing in lakes, reservoirs, wetlands and rivers, in: Biogeochemistry of inland waters: a derivative of encyclopedia of inland waters, CaryInstitute of Ecosystem Studies Millbrook, NY, USA, 2009.

Roland, F., Lobão, L. M., Vidal, L. O., Jeppesen, E., Paranhos, R., and Huszar, V. L. M.: Relationships between pelagic bacteria and phytoplankton abundances in contrasting tropical freshwaters, Aquat. Microb. Ecol., 60, 261-272, https://doi.org/10.3354/ame01429, 2010.

Roland, F., Huszar, V., Farjalla, V., Enrich-Prast, A., Amado, A., and Ometto, J.: Climate change in Brazil: perspective on the biogeochemistry of inland waters, Braz. J. Biol., 72, 709-722, https://doi.org/10.1590/S1519-69842012000400009, 2012.

Schindler, D. W.: Evolution of phosphorus limitation in lakes, Science, 195, 260-262, 1977.

Stedmon, C. A. and Markager, S.: The Optics of Chromophoric Dissolved Organic Matter (CDOM) in the Greenland Sea: An Algorithm for Differentiation between Marine and Terrestrially Derived Organic Matter, Limnol. Oceanogr., 46, 2087-2093, https://doi.org/10.4319/lo.2001.46.8.2087, 2001.

Stubbins, A., Lapierre, J. F., Berggren, M., Prairie, Y. T., Dittmar, T., and del Giorgio, P. A.: What'sin an EEM? Molecular signatures associated with dissolved organic fluorescence in boreal Canada, Environ. Sci. Technol., 48, 10598-10606, https://doi.org/10.1021/es502086e, 2014.
Suhett, A. L., Amado, A. M., Bozelli, R. L., Esteves, F. A., and Farjalla, V. F.: O papel da foto-degradação do carbono orgânico dissolvido (COD) nos ecossistemas aquáticos, Oecol. Bras., 10, 186-204, 2006.

Teixeira, M. C., Azevedo, J. C. R., and Pagioro, T. A.: Photo-degradation effect on dissolved organic carbon availability to bacterioplankton in a lake in the upper Paraná river floodplain, Acta Sci., 35, 47-54, https://doi.org/10.4025/actascibiolsci.v35i1.11054, 2013.

Tranvik, L. J., Downing, J. A., Cotner, J. B., Loiselle, S. A., Striegle, R. G., Ballatore, T. J., Dillon, P., Finlay, K., Fortino, K., Knoll, L. B., Kortelainen, P. L., Kutser, K. T., Larsen, S., Laurion, I., Leech, D. M., McCallister, S. L., McKnight, D. M., Melack, J. M., Overholt, E., Porter, J. A., Prairie, Y., Renwick, W. H., Roland, F., Sherman, B. S., Schindler, D. W., Sobek, S., Tremblay, A., Vanni, M. J., Verschoor, A. M., von Wachenfeldt, E., and Weyhenmeyera, G. A.: Lakes and reservoirs as regulators of carbon cycling and climate, Limnol. Oceanogr., 54, 2298-2314, 2009.

Vitousek, P. M., Mooney, H. A., Lubchenco, J., and Melillo, J. M.: Human Domination of Earth's Ecosystems, Science, 277, 494 499, https://doi.org/10.1126/science.277.5325.494, 1997.

Weishaar, J. L., Aiken, G. R., Bergamaschi, B. A., Fram, M. S., Fugii, R., and Mopper, K.: Evaluation of specific ultraviolet absorbance as an indicator of the chemical composition and reactivity of dissolved organic carbon, Environ. Sci. Technol., 37, 47024708, 2003.

Wetzel, R. G., Hatcher, P. G., and Bianchi, T. S.: Natural photolysis by ultraviolet irradiance of recalcitrant dissolved organic matter to simple substrates for rapid bacterial metabolism, Limnol Oceanogr., 40, 1369-1380, 1995.

Zhang, Y., Liu, X., Osburn, C. L., Wang, M., Qin, B., and Zhou, Y.: Photobleaching Response of Different Sources of Chromophoric Dissolved Organic Matter Exposed to Natural Solar Radiation Using Absorption and Excitation-Emission Matrix Spectra, PLoS ONE, 8, e77515, https://doi.org/10.1371/journal.pone.0077515, 2013.

Zhang, Y., Van Dijk, M. A., Liu, M., Zhu, G., and Qin, B.: The contribution of phytoplankton degradation to chromophoric dissolved organic matter (CDOM) in eutrophic shallow lakes: field and experimental evidence, Water Res., 43, 4685-4697, 2009.

Zweifel, U. L., Wikner, J., Hagström, A., Lundberg, E., and Norrman, B.: Dynamics of dissolved organic carbon in a coastal ecosystem, Limnol. Oceanogr., 40, 299-305, 1995. 